\title{
PROPERTY AND THE RULE OF LAW
}

\author{
Lisa M. Austin* \\ University of Toronto Faculty of Law
}

This paper offers a new framework for thinking about the relationship between the common law of property and the rule of law. The standard way of framing this relationship is within the terms of the form/substance debate within the literature on the rule of law: Does the rule of law include only formal and procedural aspects or does it also encompass and support substantive rights such as private property rights and civil liberties? By focusing on the nature of common-law reasoning, I wish to question the form/substance dichotomy that frames this debate and to show that the formal aspects of the rule of law are in fact principles widely adopted within the practice of common-law reasoning and as such play a large role in shaping the substantive content of common-law property rights. Understanding this has implications beyond the relationship between property law and the rule of law.

\section{INTRODUCTION}

This paper is about the relationship between the substance of property-law doctrines and the formal principles of the rule of law in the common law of property. It might instead be called "What Happened to Law in Property Law?" for one of its claims is that property theory has focused too much on the concept of and justifications for ownership and has ignored the important role that a certain set of legal ideas-the rule of law-plays in shaping substantive property doctrine. By the rule of law I mean the eight principles of legality outlined by Lon Fuller in The Morality of Law: generality, publicity, nonretroactivity, clarity, noncontradiction, possibility of compliance, stability, and congruence between official action and declared rule. ${ }^{1}$ Although Fuller himself controversially considered these to be part of the "internal morality" of the law, I make no such claim here. Instead, I simply accept these principles as describing a number of core elements of the rule of law, a

*I would like to thank the participants at the New York University Property Theory Workshop (July 2010), the Law and Society Workshop at the University of British Columbia Law School (February 2011), and the Private Law Theory Workshop (McGill University, April 2011) for their many helpful comments on earlier versions of this paper. I would also like to thank Alan Brudner, Hanoch Dagan, David Dyzenhaus, Angela Fernandez, Robert Gibbs, Dennis Klimchuk, Amnon Lehavi, James Penner, Denise Réaume, Henry Smith, Simon Stern, Stephen Waddams, Ernie Weinrib, and Arnold Weinrib for their helpful comments and conversations in relation to earlier drafts and Catherine Marchant for her outstanding research and editing work. Finally, I would like to thank my two anonymous reviewers for their excellent comments.

1. LON L. Fuller, THE Morality OF LAW (rev. ed. 1969). 
position that even Fuller's critics endorse. ${ }^{2}$ These formal aspects are usually understood to encompass two basic functions of law: (1) that law provides guidance to individuals, enabling them to plan their activities, either in light of potential legal liability or in light of the exercise of legal powers; and (2) that law constrains the arbitrary exercise of state power (whether by judges or other officials). The point of this paper is to highlight the pervasiveness of these formal principles in common-law reasoning and their role in shaping substantive common-law doctrine in the area of property law. ${ }^{3}$

That there is a relationship between property and the rule of law is old news, albeit highly contested. Traditionally twinned with contract, property has been seen by some liberals as an essential element of individual liberty and, in this guise, demarcates a constraint on governmental authorityincluding the authority of legislatures to regulate in a manner that changes these common-law liberties. The most prominent recent champion of this view is Richard Epstein. In his book Design for Liberty: Private Property, Public Administration, and the Rule of Law, Epstein argues that only the rights of ownership, along with contract, can secure individuals against the arbitrary exercises of authority that are one of the central concerns of the rule of law. ${ }^{4}$ Let me call this the "substantivist" view, for it contrasts strongly with what I will call the "formalist" view of the demands of the rule of law. The formalist position, recently championed by Jeremy Waldron in his Hamlyn lectures, emphasizes that the rule of law places many formal demands on legal norms - that they be general, public, certain, and so on-but does not demand any particular substance for those norms. ${ }^{5}$ As many others argue, to think otherwise is to confuse the rule of law with the rule of "good law," or a vision of law as connected to ideals of substantive justice. ${ }^{6}$ Whether one thinks that there is some intrinsic relationship between property and the rule of law or one denies it, therefore, would appear to turn on whether one sees the rule of law as embracing substantive norms or as instead remaining merely formal in its expression.

Instead of taking sides, this paper rejects the terms of this debate. There is a different and, in my view, better way of understanding the relation between form and substance in relation to property. Many of the core elements of the private law of property are matters of common law rather than statute. These

2. See, e.g., Joseph Raz, The Rule of Law and Its Virtue, 93 Law Q. REv. 195 (1977). He casts the rule of law as principles that go to the effectiveness of the law and not to the question of what law is, but offers a list very similar to Fuller's. This is also Hart's view; H.L.A. HART, THE CONCEPT OF LAW (1961), at 202.

3. I am indebted to the work of Ernest Weinrib; see Ernest J. Weinrib, Private Law and Public Right, 61 U. Toronto L.J. 191 (2011). Weinrib makes this point in relation to Kant's understanding of the demands of "public right" and how it can modify private rights, where public right includes ideas such as publicity and systematicity. In contrast, this paper is an attempt to think about these ideas outside of a Kantian framework for private liability.

4. Richard Epstein, Design for Liberty: Private Property, Public Administration, and the RULE OF LAW (2011).

5. Jeremy Waldron, The Rule of LaW and the Measure of Property (2012).

6. Raz, supra note 2. 
are two very different modes of lawmaking and, as I outline below, they have different ways of responding to rule-of-law concerns. The key to reframing the form/substance debate is to focus on the common law and switch from thinking about it as a body of norms, or even as norms protected through particular institutional arrangements, to thinking about it as a social practice of reasoning. My claim is that the formal principles of legality are routinely adverted to in common-law reasoning and consequently help to shape the substance of doctrine. In short, there is no "substance" in the common law of property that can be easilty separated from "form."

By shifting the terms of the form-and-substance debate, my account potentially contributes to property theory more generally in a number of ways. For example, although nothing in the argument of this paper is meant to suggest that rule-of-law values are the only values needed to understand the common law of private ownership, I am making the claim that the relationship between formal rule-of-law values and other substantive values in the common law is more complex than is usually recognized in the literature on the nature of ownership. This suggests some caution in utilizing a methodology that analyzes the idea of ownership from the starting point of prelegal "state of nature" stories or some other moral framework and then looks to legal cases as confirmation of this idea of ownership. ${ }^{7}$ On my account, legal cases about private property are not "data" about an idea of ownership capable of being understood in isolation from consideration of the significant role played by rule-of-law values.

My account also suggests that comparisons between common-law jurisdictions and other legal systems of property must take into account the manner in which other legal systems adopt and implement rule-of-law considerations. ${ }^{8}$ Just as legislative lawmaking and common-law adjudication are different modes of legal ordering that are shaped by rule-of-law values but which provide different types of channels for the introduction and expression of these values, other types of legal systems such as the civilian tradition might also share in rule-of-law values but express them in unique ways. Both similarities and differences in the treatment of "ownership" between such systems might therefore be due to rule-of-law considerations rather than other values. Comparative analysis needs to take this into account.

A focus on the rule of law also provides an alternative framework for assessing the contributions of the information-cost approach to property law. Its main proponents, Thomas Merrill and Henry Smith, insist that

7. Here I would include traditional "state of nature" stories that seek to understand what is normative about property in the absence of the state and law. See, e.g., ARTHUR RIPSTEIN, Force and Freedom: Kant's Legal and Political Philosophy (2009). I would also include contemporary neo-Aristotelians and their emphasis on virtue ethics as a lens through which to analyze property. See, e.g., Eduardo M. Peñalver, Land Virtues, 94 Cornell L. Rev. 821 (2009).

8. See, e.g., Thomas W. Merrill \& Henry E. Smith, Optimal Standardization in the Law of Property: The Numerus Clausus Principle, 110 YALE L.J. 1 (2000), for a comparison of the civil-law and common-law approaches to the numerus clausus principle. 
the in rem feature of property rights - that these are rights against "the world" rather than personal rights-imposes unique informational burdens on third parties. Accordingly, the information-cost dynamics involved in coordinating large numbers of anonymous individuals in relation to their duties of abstention can explain many of property law's defining features. ${ }^{9}$ My rule-of-law focus suggests that the importance of information costs is connected to the general guidance function associated with the rule of law and is therefore not unique to in rem rights. However, in what follows I outline a number of ways in which aspects of private ownership give rise to specific versions of rule-of-law concerns-including guidance concernsthat might not arise in other nonproperty contexts. One of these aspects is indeed the in rem nature of property rights.

However, another important aspect is the fact that in addition to dutyimposing rules of abstention, property involves having and exercising legal powers. Moreover, as I outline below, the rule of law is not exhausted by its guidance function but is also concerned with nonarbitrariness. A rule-oflaw reframing of the information-cost approach to property would therefore suggest that an information-cost analysis could enrich areas of legal scholarship beyond property law by pointing to the way in which the guidance function of law influences substantive norms, but would also suggest that too exclusive an emphasis on either the in rem aspect of property or guidance itself obscures other important elements in the relationship between property and the rule of law.

Finally, my reframing of the form/substance debate suggests a new way to assess the relationship between property and freedom. Some theorists who have endorsed the "bundle of rights" view of ownership have done so in order to dislodge the view that private ownership is necessary for individual freedom and that the role of the state is to enforce private law. ${ }^{10}$ Recognizing that property is a bundle of rights that the state chooses to enforce and which can be reconfigured clears the way to endorsing state regulation aimed at ameliorating problematic disparities in the distribution of property. Such regulation, according to this line of argument, should be seen as enhancing rather than detracting from personal liberty. ${ }^{11}$ My account suggests that this debate should also attend to the idea of legal freedom-most often expressed as the idea of freedom from arbitrariness - that has often been associated with the rule of law. ${ }^{12}$ The fact that the common law of private property expresses rule-of-law values in one way does not preclude legislation from expressing them in another way. The "freedom" question within this

9. See Thomas W. Merrill \& Henry E. Smith, What Happened to Property in Law and Economics?, 111 YALE L.J. 357 (2001).

10. See, e.g., Thomas C. Grey, The Disintegration of Property, in NomOs XXII: ProperTy 69 (J.R. Pennock \& J.W. Chapman eds., 1980), at 79.

11. Id.

12. See generally Brian Tamanaha, On the Rule of Law: History, Politics, Theory (2004); see also David Dyzenhaus, How Hobbes Met the "Hobbes Challenge," 73 MoD. L. REv. 488 (2009), for a description of Hobbes's account of civic freedom along these lines. 
rule-of-law framework is whether the state regulation itself expresses ruleof-law values and not whether it derogates from the common-law idea of private ownership. ${ }^{13}$

The argument of the paper proceeds as follows. First, I outline how shifting the focus of discussion of Fuller's principles of legality from a legislative paradigm to a common-law paradigm allows us to see the ways in which these principles influence substantive common-law doctrines. Taking the guidance function of the rule of law as an example, I claim that the principles of legality connected to this guidance function in fact deeply influence the ways in which common-law reasoning is bound up with community practices and ideas of social order. Second, drawing at least partially upon J.W. Harris's taxonomy regarding property institutions, I look at the relationship between the rule of law and aspects of property doctrine dealing with control powers, title conditions, and trespass rules. ${ }^{14}$ In relation to control powers, I outline how shifting from a focus on liability rules to a focus on legal powers can show why some areas of the common law of property appear more demanding in relation to rule-of-law concerns such as nonretroactivity and clarity. In relation to title conditions, I argue that the common law of possessory title is deeply shaped by rule-of-law concerns regarding publicity. In relation to trespass rules protecting the right to exclude, I claim that the law is strongly influenced by rule-of-law concerns regarding arbitrariness. Finally, I conclude by outlining some of the implications that this reframing of the form/substance debate has in relation to theories of legal reasoning more generally.

\section{FORM AND SUBSTANCE}

There are many different accounts of the rule of law, but there is widespread agreement that it at least encompasses Fuller's eight principles of legality. ${ }^{15}$ Waldron proposes that these principles be understood in terms of the formal properties of law, as contrasted with law's procedural demands or its substantive content; norms must take certain forms if they are to be legal, and this includes the formal properties of generality, clarity, and so on. ${ }^{16}$ I take up this usage here and bracket other controversies regarding

13. For example, a statute that retroactively cancels building permits that individuals have relied upon to make investments is quite different from a statute that operates prospectively, treats all similarly situated individuals in the same manner, and provides robust procedural safeguards in relation to obtaining those permits.

14. J.W. Harris, Property \& JUSTICE (1996). Harris uses the terms "trespassory rules" and "ownership spectrum." The latter includes "use-privileges" and "control-powers" and in some cases "powers of transmission" ( $i d$. at 5). Later he states that "title conditions of some kind, as well as trespassory rules and ownership interests, are a necessary feature of a property institution" ( $i d$. at 40).

15. FULLER, supra note 1.

16. Jeremy Waldron, The Concept and the Rule of Law, 43 GA. L. REV. 1 (2008); Jeremy Waldron, The Rule of Law and the Importance of Procedure, in Nomos L: GeTting to THE Rule of LaW 3 
whether these principles are Fuller's "internal morality" of law, an expression of law's "virtues," 17 or the principles of planning inherent in the legal enterprise, ${ }^{18}$ and the extent to which the rule of law embraces more substantive content. ${ }^{19}$ These formal properties in turn connect to the rule of law's function in providing guidance and in constraining the arbitrary exercise of power.

Fuller frames his influential description of the eight principles of legality in terms of a parable about a monarch, Rex, who passes legislation rather than having judges deciding cases within the common-law tradition. ${ }^{20}$ In order to understand the way in which these formal principles influence the substance of private-law norms as expressed in common-law doctrine, we need to shift away from their legislative framing in the parable about Rex and toward a common-law reframing. ${ }^{21}$ The most important element of the shift from a legislative paradigm of law toward a common-law paradigm is to move away from understanding law in terms of enacted norms. ${ }^{22}$ Instead, we need to view it as primarily a social practice of reasoning. Gerald Postema argues that for classical common lawyers:

Law was regarded not as a structured set of authoritatively posited, explicit norms, but as rules and ways implicit in a body of practices and patterns of practical thinking all "handed down by tradition, use, [and] experience" (Blackstone 1765:i.17). These rules were the product of a process of a common practice of deliberative reasoning, and constituted the basic raw materials used in it. Common law was "reasonable usage" (Hedley 1610:175), observed and confirmed in a public process of reasoning in which practical problems of daily social life were addressed. "Custom" and "reason" were the twin foci of this conception of law. These two notions were complementary, mutually enhancing and supporting, and mutually qualifying. ${ }^{23}$

Several elements of this classical common-law position are important for the following discussion of the principles of legality, having to do with this

(James E. Fleming ed., 2011). Waldron notes that Fuller sometimes spoke of these in terms of procedure.

17. See Raz, supra note 2.

18. See Scott Shapiro, Legality (2011).

19. See generally Paul P. Craig, Formal and Substantive Conceptions of the Rule of Law: An Analytic Framework, Pub. L. 467 (1997); TAManaha, supra note 12; Global PersPectives on the Rule of LAW (James J. Heckman, Robert L. Nelson \& Lee Cabatingan eds., 2010).

20. Fuller, supra note 1. He does have a few common-law examples in his text, but this is not his focus. This choice is no doubt meant to show clearly that the failure of a legal system as a legal system does not depend on either a failure of authority or a failure of democratic legitimacy but could instead arise from a failure to adhere to what he calls the "internal morality" of the law.

21. Fuller's discussion is not entirely legislative, and his work in contract law is alive to the influence of formal considerations, although he does not connect this to his ideas on the principles of legality. See Lon L. Fuller, Consideration and Form, 1 CoLum. L. Rev. 799 (1941).

22. A.W.B. Simpson, The Common Law and Legal Theory, in OXFORD EsSAYS IN JURISPRUDENCE 77 (A.W.B. Simpson ed., 1973).

23. Gerald J. Postema, Philosophy of the Common Law, in The Oxford HANDBook OF JuRISPRUDENCE AND Philosophy OF LAW 588 (Jules Coleman \& Scott Shapiro eds., 2002), at 590. 
"twin foci" of reason and custom. First, on this view common-law judgments reflect the result of a practice of interpretation of existing legal practices and ways of thinking rather than law that is enacted and applied. Second, the resulting doctrine is always closely tethered to the practice of reasoning, so that what the case is thought to "hold" cannot be neatly separated from the reasoning of the case and the practical problem being addressed. Third, community practices are integral to this understanding of law in a number of ways, including providing evidence of implicit norms and providing a way to confirm the reasonableness of the law that was meant to address social life. Fourth, the common law reflects a complex idea of the relation between law and social order, where law is constitutive of social order but social order is also constitutive of law.

These elements of the classical common-law position can reorient our thinking about the relationship between the common law and the rule of law. It is important that we understand the formal demands of the rule of law in relation to a practice of reasoning rather than in relation to specific norms. Equally important is that this practice of reasoning is integrally bound up with community practices and ideas of social order. My claim is that the principles of legality are a set of considerations that are pervasive within this practice of common-law reasoning and, because of this, help to shape the substance of common-law doctrine.

To illustrate this position, consider the guidance function of the rule of law. Many of the principles of legality-including generality, nonretroactivity, clarity, and stability-enable individuals to plan their actions in order either to exercise legal powers or to avoid legal liability. There are many ways of describing the common law that highlight its deficiencies in relation to guidance. Below I outline several and then show how focusing on the common law as a practice of reasoning in the manner just described reveals that the common law is in fact deeply preoccupied with guidance.

One way in which the common law looks deficient is in relation to Fuller's first principle of legality, generality. As he argues, law consists of general principles because "to subject human conduct to the control of rules, there must be rules." ${ }^{24}$ For law to govern individual conduct, individuals must be able to self-regulate in light of known general principles. ${ }^{25}$ But the common law has always emphasized the particular case over general principles, resulting in a body of law that while having a number of "rules" (the rule against perpetuities, for example), is seriously distorted if characterized as a body of rules. ${ }^{26}$ Although it is possible to describe a holding in a case in a rulelike manner, in the common-law tradition this is a provisional interpretation that is open to revision in light of the facts and reasons of the case, in light of new contexts that test the ideas, and in light of new interpretations

24. Fuller, Morality, supra note 1 , at 49.

25. Fuller contrasts this with an employer "standing over the employee and directing his every action." Id. at 47.

26. Simpson, supra note 22. 
of different lines of cases and areas of case law. Even if we shift away from "rules" to "principles," it often requires considerable interpretation to discern the general principles thought to be running through the cases, calling into question their ability to guide conduct in any straightforward manner. Moreover, even once something like a principle is announced as the way to understand a line of cases, this principle is itself subject to potential reinterpretation in light of subsequent cases. ${ }^{27}$ Indeed, one of the very striking aspects of common-law decisions is the way in which courts are quite willing to reinterpret past statements of principle while often unwilling to say that a past case was wrongly decided on the facts. ${ }^{28}$

The common law appears deficient in relationship to the guidance function of law in several other ways as well. One potential problem is with the principle of nonretroactivity. As Schauer argues, common-law rules are "created in the very process of application" and are therefore applied to facts that arise "prior to the establishment of the rule." ${ }^{29}$ Fuller acknowledges that retroactive laws are sometimes necessary, especially if they remedy some other defect in the law. ${ }^{30} \mathrm{He}$ also suggests that if we always required the law to respect individual reliance interests, then "the whole body of our law would be ossified forever." 31 However, none of this responds to the charge that the common law as a whole is deeply characterized by retroactivity. Many of the criticisms of the common law in relation to the principles of generality and nonretroactivity also apply in relation the principles of clarity and stability. Indeed, in Bentham's well-known attack, he takes uncertainty and inconsistency as among the chief defects of the common law. ${ }^{32}$

Matters look different, however, if we take seriously both the way in which the common law is a practice of reasoning rather than a set of rules and the way in which this practice intersects with community practices and ideas of social order in various complex ways. Although the common law is not best characterized as a system of general rules, common-law reasoning itself is driven by a concern for generality. That "like cases should be decided alike" is one of the reasons underlying the idea of precedent and the manner in which it constrains subsequent decisions. ${ }^{33}$ This concern for generality

27. This is why Levi, in his classic text on legal reasoning, argues that the common law does not proceed in either an inductive or a deductive basis, but is circular; EDWARD H. LEVI, An Introduction to Legal REASONING (rev. ed. 1962). Because "circular" is often used more generally as a term indicating a logical fallacy, perhaps a better description would be that the common law is an iterative process that constantly moves back and forth between facts and principle.

28. Even the idea of stare decisis is not part of the classical common-law paradigm but emerged in the eighteenth century. See Simpson, supra note 22, at 77; and NeIL DuXbURY, THE NATURE AND Authority OF PRECEDENT (2008).

29. Frederick Schauer, Is the Common Law Law?, 77 CALIF. L. Rev. 455 (1989), at 455. See also Frederick ScHAUER, THINKING Like A LAWYER (2009), at 114.

30. Fuller, MORALiTy, supra note 1, at 53.

31. Id. at 60 (in particular responding to arguments regarding tax laws).

32. See Gerald J. Postema, Bentham and the Common Law Tradition (1986), at 295.

33 . With respect to how we understand the different ideas of binding and persuasive precedents, there are a number of important issues that are beyond the scope of this discussion. 
is not restricted to the binding force of precedent, for many point out that the common law valued ideas such as consistency between similar cases long before the doctrine of stare decisis emerged. ${ }^{34}$ Even when not following binding authority, courts seek analogies between cases as well as interpreting lines of cases as revealing general principles, which is a more complex way of showing how cases are alike. Moreover, when courts say that a past statement of principle is wrong, they often do so by offering a new interpretation of past cases that purports to offer a better articulation of their generality. ${ }^{35}$ Finally, even when courts feel that there is no applicable precedent-binding or otherwise-and look at the possible consequences of making a particular determination, they are often asking whether their decision can be "universalized." 36

Although we can find the principle of generality operating in the practice of common-law reasoning, we might ask whether the common-law version is the kind of generality that can guide conduct. Here, a focus on community practices and social norms is important. As Postema argues, it is a mistake to think of the guidance function of law in terms of legal norms "addressed to individual law-subjects." 37 Instead, law guides "by giving shape to, and taking its shape from, the network of informal social practices" that individual lawsubjects participate in. ${ }^{38}$ Theorists advocating an information-cost approach to property, which places significant emphasis on the importance of notice if property is to fulfill its coordinating function, make a similar point regarding the need for property to accord broadly with social norms in order to be publicly accessible. ${ }^{39}$ All of this suggests that we should understand the guidance function of the common law in relation to social practices and the ways in which the law constitutes them and in turn is constituted by them.

Once we understand the importance of social practices, we can also appreciate the manifold ways in which common-law judges are in fact acutely sensitive to the principle of nonretroactivity. To take one prominent example, in Moore v. Regents of University of California, the Supreme Court of California was reluctant to recognize property interests in bodily tissue, partly for the reason that to do so would disrupt existing research practices

34. DuXBury, supra note 28 , at 37 .

35. This reflects the ongoing influence of the traditional common-law view that as between the parties a particular decision was res judicata, but the "legal significance of a case ... lay in the nature and quality of the argument in the precedent case." Gerald J. Postema, Classical Common Law Jurisprudence (Part II), 3 Oxford U. CommonweAlTh L.J. 1 (2003), at 12. Postema also notes that this was more a matter of "local coherence" that remained concerned with the workability of the law on the ground than the kind of grand coherence of abstract theory. See Gerald J. Postema, Classical Common Law Jurisprudence (Part I), 2 Oxford U. CommonwEALTH L.J. 155 (2002), at 178.

36. Neil MaCCormick, Rhetoric ANd the Rule of LaW (2005), at 103.

37. Gerald J. Postema, Conformity, Custom, and Congruence: Rethinking the Efficacy of Law, in The Legacy of H.L.A. Hart: Legal, Political and Moral philosophy 53 (Matthew Kramer ed., 2008).

38. Id. at 56.

39. Thomas W. Merrill \& Henry E. Smith, The Morality of Property, 48 WM. \& MARY L. REv. 1849 (2007). 
that are premised on the idea of nonownership. ${ }^{40}$ In other words, the majority was concerned about the significant retroactive effect of recognizing ownership rights in relation to tissue, especially in relation to downstream users of the tissue in medical research. When dealing with property rights that are held against the world, rather than against specific individuals, these third-party effects can be far-reaching. ${ }^{41}$

Sometimes, however, these considerations may point to the need to change the law rather than resist such change. The effect of some legal decisions is to change the law in order to make it more consistent with existing community practices. In such cases the legal decision does not have a practical retroactive effect on actual relations-it instead remedies what has become a legal formality interfering with existing community practices. For example, although courts have been reluctant to recognize property interests in bodily tissue, many courts have readily recognized property-like protection for personality rights and have even explicitly linked this to a recognition of existing commercial reality and practices for professional athletes and celebrities. ${ }^{42}$ In such cases the recognition of property rights does not disrupt existing practices but reflects them more accurately than does the previous state of the law. ${ }^{43}$

In short, considerations such as generality and nonretroactivity, along with related ideas of clarity and stability, inform some of the characteristic modes of common-law reasoning and the particular ways in which community practices influence this reasoning. Far from being deficient in relation to guidance, the common law turns out to be deeply concerned with it. Nonetheless, as the following section outlines, some aspects of property law are more clear, stable, general, and nonretroactive than other areas of common-law doctrine. The reason for this, I argue, lies in the distinctive nature of legal powers rather than in legal liability.

\section{GUIDANCE AND CONTROL POWERS}

Property law is replete with legal doctrines that specify control powers rather than liability rules. This distinction maps onto Hart's discussion of the difference between laws that "impose duties or obligations" and laws that "provide individuals with facilities for realizing their wishes, by conferring legal powers upon them to create, by certain specified procedures and subject to certain conditions, structures of rights and duties within the coercive

40. Moore v. Regents of University of California, 793 P.2d 479 (Cal. 1990). The U.S. case first recognizing a right of "publicity" also did so in the context of existing practices and expectations in relation to the marketing of celebrity images. See Haelan Labs. Inc. v. Topps Chewing Gum, Inc., 202 F.2d 866, 868 (2d Cir. 1953).

41. See Merrill \& Smith, Optimal, supra note 9.

42. See, e.g., Krouse v. Chrysler Can., [1974] 1 O.R. (2d) 225 (Can. Ont. C.A.).

43. The resulting social conservatism is not always a good thing and is sometimes an argument for why legislative lawmaking, with its prospective focus, should prevail. See, e.g., Jennifer E. Rothman, The Questionable Use of Custom in Intellectual Property, 93 VA. L. REv. 1899 (2007). 
framework of law." ${ }^{4}$ Hart includes within these power-conferring laws those pertaining to contracts and wills, although his primary concern is laws that confer power of a public rather than private nature. ${ }^{45}$ Trespass rules, involving duties of abstention on the part of nonowners, are an example of liability rules. However, other central property-law doctrines that determine powers of alienability, such as what kinds of estates can be conferred (e.g., life estate, conditional estate, leasehold) or what kinds of obligations can be created that "run with the land" (servitudes), are very much about control powers rather than liability rules. ${ }^{46}$

The significance of legal powers to the question of how the common law instantiates the guidance function of the rule of law is that the exercise of powers often operates much more like a specific address to a particular individual than like the more general address of the law discussed in the previous section. Two aspects of legal powers show why they are like norms addressed to particular individuals. The first is that the law itself specifies what actions must be done in order to secure desired legalconsequences, and these consequences change the normative position of individuals in relation to a preexisting background of law. For example, to transfer title validly, an owner must conform to a number of legal formalities. The law must therefore be capable of guiding specific individuals-or, more accurately, their legal advisors - in the exercise of their powers and must be able to indicate clearly the relevant legal steps to be taken. ${ }^{47}$

The second important aspect of legal powers is that private individuals exercise them in relation to other specific persons, and so this exercise actually operates as an address to an individual law-subject rather than as a general address. For example, a testator might transfer a conditional estate and retain a right of reentry that can be triggered by the recipient's breach of the condition. This condition concerns the new owner of the estate, not the community more broadly. As I outline below, these features of legal powers suggest that the guidance function of the rule of law takes on different contours in this context than it does in relation to liability rules.

There are many examples of common-law judges expressing a strong concern for both certainty and the protection of reliance interests in relation to legal powers associated with property. A relatively recent Canadian case regarding positive covenants is a good example of this. In Durham

44. HART, supra note 2, at 27.

45. Id. at 28 .

46. This would also describe the "right to manage," as discussed in A.M. Honoré, Ownership, in OXFORD EsSAYS IN JURISPRUdENCE 107 (A.G. Guest ed., 1961), which is the "right to decide how and by whom the thing owned shall be used" and which depends "on a cluster of power," including the power of licencing; $i d$. at 116. This idea of control powers would at least partly include "right to the capital," which Honore describes as "the power to alienate the things," as well as "the liberty to consume, waste or destroy the whole or part of it"; $i d$. at 118.

47. Neil MacCormick and Joseph Raz, Voluntary Obligations and Normative Powers, 46 Proc. Aristotelian Soc'y 59 (Supp.) (1972), at 80; Joseph Raz, Practical Reason And Norms (1975), at 103. 
Condominium Corp. No. 123 v. Amberwood Investments Ltd., et al., ${ }^{48}$ the Ontario Court of Appeal dealt with the question of whether positive covenants were enforceable against the successor in title to the covenantor. This is an area where there is a long-standing "rule," and this rule is quite clear: positive covenants do not run with the land. ${ }^{49}$ The court was asked nonetheless to revisit this rule and at least to adopt an exception that had been recognized within English common law. ${ }^{50}$ The majority accepted the argument that the traditional rationales behind the rule were no longer relevant in the context of modern conveyancing, but still declined to change the rule. ${ }^{51}$ The reasons offered included the fact that individuals structure their commercial relationships on the basis of such rules; changes should therefore be made prospectively by the legislature rather than by the courts so as not to disrupt those relationships. In other words, reliance interests arise in the context of legal powers because individuals exercise these in order to secure specific legal consequences for their relationships and plan their activities in reliance upon these legal consequences.

These considerations led the court to a very strong expression of the concern for nonretroactivity: courts should change such rules only where there has been a change in "commercial reality" and those changed commercial practices make the hardship caused by the outdated rule "acute and widespread." 52 In this way the court gave effect to the unique reliance interests that arise with legal powers: people rely upon the law, not existing social practices, and do so precisely in order to effect normative changes against preexisting background conditions.

These ways in which the considerations of nonretroactivity, clarity, and stability intersect with legal powers indicate strong rule-of-law reasons for judicial conservatism in relation to the common law of property. As Merrill and Smith point out in their discussion of the numerus clausus principle, legislative decision-making is superior to common-law decision-making when making significant changes to property law because of the way in which it can promote "clarity, universality, comprehensiveness, stability,

48. Durham Condo. Corp. No. 123 v. Amberwood Invs. Ltd., [2002] 58 O.R. (3d) 481 (Can.).

49. $I d$. at para. 17 .

50. The exception was the "doctrine of benefit and burden" recognized in Halsall v. Brizell, [1957] 1 All E.R. 371 (U.K.).

51. Durham Condo., supra note 48. These rationales were that positive covenants would "tend to render land inalienable" and that the existence of these covenants is difficult for others to ascertain "because they do not normally have a physical manifestation." See id., para. 37, citing Ontario Law Reform Commission (OLRC), Report on Covenants AFFecting Freehold Land (1989), at 21. The OLRC argues that the first rationale does not reflect the fact that in urban areas such covenants can actually enhance alienability by protecting desirable neighborhood amenities and the second rational does not reflect the fact that with land registries these covenants can be made public. I am not commenting here on whether this is a persuasive account of the rationale behind the rule, just noting that the Ontario Court of Appeal accepted it.

52. Durham Condo., supra note 48 at para. 49. 
prospectivity, and implicit compensation."53 Most of these considerations are expressions of the rule of law. Although my analysis indicates that the common law expresses many of these rule-of-law values, it does not necessarily do so in the same way as other modes of lawmaking. What it lacks is the ability that legislatures have to change the law prospectively; instead it must rely upon changing social practices to mitigate retroactive effects. It also lacks the ability to provide compensation to those whose reliance interests are affected by changes in the law. What is important for the present discussion is that judicial conservatism in relation to property law's control powers is not necessarily a strong judicial endorsement of any form of private ownership or deference to the democratic legitimacy of legislatures so much as an expression of the demands of the rule of law in relation to common-law adjudication.

The exercise of legal powers intersects with rule-of-law principles in another distinctive manner having to do with validity. There are a number of ways in which the law permits owners to place conditions on the transfer of estates or impose them when creating legal obligations with owners of neighboring parcels of land, such as through the creation of a restrictive covenant. Courts can strike out these conditions on the grounds that they are too uncertain, constitute an unreasonable restraint on alienation, or are against public policy. One way to view these grounds for invalidity is to see them all as different aspects of public policy marshaled by the courts to limit the exercise of private power. ${ }^{54}$ My argument here is that what these doctrines show is that the courts will void conditions that fail in relation to basic principles of legality. In other words, when exercising the legal powers associated with ownership, an owner must act in accordance with the rule of law.

What it means for an individual to exercise private legal powers in conformity with the rule of law is not necessarily the same thing as what it means for the common law more generally to conform to the rule of law. For example, as already discussed, if the common law operates as a general address, then its complex relationship with existing social practices is one way that it achieves clarity on the ground. In contrast, when a testator attaches a condition to the transfer of her estate, she changes the nature of specific legal relations in a way that gives rise to distinctive guidance concerns.

For one thing, a change in title requires clarity regarding the specific person who is to become the new owner. Additionally, the imposition of a condition changes the basic rights and obligations that attach to an estate but does so only for the specific person bound by the condition and not for

53. See generally Merrill \& Smith, What Happened, supra note 9, at 61. This also suggests that the numerus clausus principle is required by the rule of law. However, a full discussion of this principle as an expression of the rule of law is beyond the scope of this paper.

54. See Bruce Ziff, Principles of Property LaW (4th ed. 2006), at 228ff. He points to two categories of public policy. The first is policies that relate to property, such as efficiency considerations, and the second is broader social policy considerations. 
all estate holders more generally. Accordingly, such conditions can be found void for uncertainty-without sufficient clarity they simply cannot operate as the individual addresses that they are ${ }^{55} \mathrm{~A}$ condition may also be found void if it imposes an unreasonable restraint on alienation or is contrary to public policy. Both of these are expressions of the value of consistency in the law, which is connected to a number of Fuller's principles, including noncontradiction. For example, an unreasonable restraint on alienation is said to be "repugnant" to the idea of a fee simple, which is understood to include the possibility of alienation. ${ }^{56}$ Legally transfering a fee simple but with a condition that results in a substantial restraint on alienability is to do something contradictory if the legal nature of a fee simple is partially constituted by its alienability. ${ }^{57}$

A similar argument can be made in relation to the invalidation of conditions on the grounds of public policy. In these cases the courts routinely look to other analogous areas of the law in order to find objective evidence of public harm rather than the "idiosyncratic inferences of a few judicial minds." 58 "Harm to the public" is not an all-things-considered substantive inquiry but one that is dominated by concern for consistency with values already expressed in other areas of the law.

In sum, in order fully to appreciate the role played by the guidance function of the rule of law as well as its specific contours, we need to shift our focus from the liability rules of property law to legal powers. Legal powers give rise to unique reliance concerns that generate strong rule-oflaw reasons for judicial conservatism in relation to doctrinal changes. The principles of legality also help to define the terms of the valid exercise of control powers in property law. Both of these are clear examples of how the formal aspects of the rule of law shape substantive property-law doctrine.

In the following section, I outline how a focus on both guidance and control powers can also clarify title conditions in property law, which are the conditions that must be satisfied for a person to be considered an "owner." As As argue, title conditions are motivated by guidance concerns,

55. The test for uncertainty is different for conditions precedent and for conditions subsequent, a difference that can be explained through the unique reliance interests that arise in relation to the latter but not the former. With a condition subsequent, breach of the condition can give rise to the loss of the estate after it has already vested. See generally Clavering v. Ellison, [1859] 7 H.L.C. 707 (U.K.); Sifton v. Sifton, [1938] A.C. 656 (Can.).

56. Re Rosher, [1884] 26 Ch. D. 801 (U.K.). This has also been defended on policy grounds; see Laurin v. Iron Ore Co. of Can. (1977) 19 Nfld \& P.E.I.R. 111 (Can.).

57. This does not have to be taken to reflect a judicial endorsement of the nature of ownership in general, for there is a source in the positive law routinely cited for this proposition: the Statute of Quia Emptores of 1290, which abolished the practice of subinfeudation but made substitution possible. It is this substitution (that another individual can be substituted for you as the holder of the property interest) that results in the possibility of free alienability. See J.H. BAKER, AN Introduction to English Legal History (4th ed. 2007), at 260ff, for a richer discussion of the historical and feudal roots of our idea of alienability.

58. Canada Trust Co. v. Ontario Human Rights Commission, [1990] 74 O.R. (2d) 481 (Can. Ont. C.A.), at para. 36, citing Re Millar, [1938] S.C.R. 1 (Can.) at 7.

59. J.W. Harris defines title conditions as "the conditions, within a particular property institution, which must be satisfied before a person can slot into the protection of its trespassory 
but this guidance must be understood in relation to both the idea of legal powers and the idea of legal liability.

\section{GUIDANCE AND TITLE CONDITIONS}

Publicity is central to the guidance function of the rule of law, for legal subjects can be guided by the law only when they can ascertain and selfapply its terms. Fuller includes publicity as his second principle of legality and discusses this in terms of promulgation, or the formal requirements by which legislation is made public. ${ }^{60}$ If the paradigm of publicity is published statutes, then the common law looks inadequate. Reliable court reports of decisions are a fairly late arrival in the history of the common law, ${ }^{61}$ and the "public" meaning of decisions arguably relies upon a much more complex labyrinth of interpretive practices than do statutory codes. Nonetheless, as discussed above, the practice of common-law reasoning intersects in numerous ways with existing social practices and public understandings. If we shift away from ideas of promulgation and look instead at how publicly understood practices ensure that law can operate in the daily lives of individuals who need to self-apply its basic components, then we can see how the common law expresses a concern for publicity.

I propose that the common law of possessory title is best understood as one of the central ways in which the common law makes private ownership consistent with publicity. For example, if part of what ownership involves is the idea that third parties have obligations in relation to the owner (e.g., the obligation to refrain from interference), then publicity would demand that these third parties know that something is owned rather than unowned. ${ }^{62}$ However, to understand the publicity of title we also need to understand why it is important to know who owns something. For this we need the idea of legal powers rather than the duty of noninterference. Third parties who obtain permission for some use or purchase some thing need to know that they do so from the person who has the legal power either to provide them with permission or to transfer title. The rules and practices specifying who is the owner of what must be clear and publicly ascertainable if ownership

rules," and benefit from whatever other ownership interests are recognized within the institution. HARRIS, supra note 14 , at 39.

60. FulLER, supra note 1 , at $49 \mathrm{ff}$.

61. Richard J. Ross, The Memorial Culture of Early Modern English Lawyers: Memory as Keyword, Shelter and Identity, 10 YALE J.L. \& Human. 229-326 (1998).

62. Indeed, an information-cost approach to the in rem aspect of the general impersonal duties of nonowners is a very fruitful way to understand the requirement of publicity in this context. Although Henry Smith's information-cost approach makes the large and diverse audience of in rem rights its central focus, he also acknowledges that the nature of the "audience" affects the formality of the law and therefore whether it is information-intensive or information-nonintensive. See Henry E. Smith, The Language of Property: Form, Context, and Audience, 55 STAN. L. REV. 1105 (2003). 
is to be a viable practice capable of operating "on the ground" in the daily lives of people.

Consider a classic common-law context for questions of possessory title and its "relative" nature: finder cases. The basic common-law position is that a finder has good title as against everyone except the true owner or someone with a superior prior claim. ${ }^{63}$ As one judge stated, this rule "must be right as a general proposition, for otherwise lost property would be subject to a free-for-all in which the physically weakest would go to the wall." ${ }^{\circ 4}$ This concern regarding a free-for-all is not about ownership so much as the maintenance of social order with respect to things. Moreover, it points to the key consideration, which is the way in which possession signals to third parties that something is owned. In the context of finders, the idea of possession functions as evidence upon which third parties can rely to tell them whom they should treat as the owner, even though the finder is not the owner. The point of possessory title is to settle the matter of title for everyone else and leave the finder and true owner to sort things out as between them. In other words, the function of the test for possession is to permit third parties to treat as owner the person who is openly acting as owner. ${ }^{65}$

What about first-possession cases, where there is no true owner? Carol Rose's influential account of possession is centered on ideas of publicity, although she herself does not use this term. What counts, she argues, is that an individual be the first to give the right kind of sign that she is claiming ownership. ${ }^{66}$ The right kind of sign, according to Rose, is one that the relevant community understands. The common law of possessory title suggests that the right kind of sign is to act publicly as an owner. In other words, the primary role of the doctrine is to tell the world that whoever happens to be in possession (acting like an owner) is to be treated as the owner. If, unlike the finders context, there are no other prior superior claims, then the first possessor in effect acquires ownership. ${ }^{67}$

If the story of possessory title is a story of the publicity of title, then we would expect the doctrine to become legally irrelevant once a legal system moves away from possessory title to more formal and systematic means of dealing with title. For example, developed legal systems now have very formal systems of title for land ownership whereby the boundaries of estates are mapped, titles to such estates are registered in formal land registries, and specific conditions are legislated that govern the legal validity of any conveyance of title. In some systems of title, such as the Torrens

63. Armory v. Delamirie, [1722] 1 Stra. 505 (U.K.).

64. Parker v. British Airways Bd., [1982] Q.B. 1004 (U.K.), at 109 (Donaldson L.J.).

65. See also HARRIS, supra note 14 , at 83 , for the point that possession means acting like an owner, although he does not connect this to title in the way that I am arguing.

66. Carol Rose, Possession as the Origin of Property, 52 U. CHI. L. REV. 73 (1985).

67. In some special contexts where the audience is "highly focused and specialized," we might expect some departures from the standard common-law approach to possessory title. For example, this is one way of thinking about whaling cases such as Swift v. Gifford, 23 F. Cas. 558 (D. Mass. 1872). See Smith, supra note 62, at 1120. 
title, the state actually guarantees that the registered owner is in fact the owner recognized at law, and the doctrine of adverse possession is usually abolished. ${ }^{68}$ However, in jurisdictions that have a land registry system that records but does not guarantee title, the doctrine of adverse possession remains. The puzzle is to understand why.

One answer is that adverse possession addresses cases of boundary disputes. Even where there are state-sanctioned descriptions of boundaries, there can be mistakes with respect to how these operate on the ground. This can occur, for example, when the historic pattern of occupation of the land does not match the official survey description, such as when a longstanding fence turns out to be in the wrong location. Although a jurisdiction might require an individual to defer to the state-sanctioned description, it might also decide that the best way to ensure clear and public boundaries that permit the degree of self-application required of property is, after a period of time, to defer to actual practices. Adverse possession provides a way of cutting off the possibility of prior claims after a period of time by deferring to the facts on the ground.

What is less clear is why courts would permit the application of the doctrine of adverse possession to deliberate trespassers rather than individuals who are mistaken about boundaries. ${ }^{69}$ In such contexts there seems to be no role for the law of adverse possession to make the fact of ownership publicly ascertainable and certain, for there is no mistake about ownership. Some courts have indeed recoiled at the idea of permitting adverse possession to operate in the context of deliberate trespassers. ${ }^{70}$ While this latter position seems more defensible from the perspective of publicity, general considerations of the rule of law in these cases are in fact quite complex. Adverse possession is not entirely a creature of the common law but arises out of the interplay between statutes of limitation, land registry systems, and the common-law understanding of possession. The result is that it is not a simple judicial task to argue that this doctrine should not operate in relation to deliberate trespassers; depending on the wording of the statute in issue, such a position can seem like unwarranted judicial lawmaking at odds with clear statutory language. Some courts have nonetheless tried to make it difficult for deliberate trespassers to succeed.

For example, in pointing to the fact that the would-be adverse possessor "deliberately embarked on a course of conduct which ultimately led to an intention to dispossess the respondents of their property," a Canadian appellate court endorsed the statement that statutes of limitations "were

68. However, some jurisdictions with a Torrens system retain the doctrine for dealing with boundary disputes. See ZIFF, supra note 54, at 125-126.

69. See, e.g., J.A. Pye (Oxford) Ltd. and Others v. Graham and Another, [2002] UKHL 30; J.A. Pye (Oxford) Ltd. and Another v. United Kingdom, [2006] App. No. 44302/02, Eur. Ct. H.R. (2005), 43 Eur. Ct. H.R. 3 (2006); J.A. Pye (Oxford) Ltd. and Another v. United Kingdom, [2008] App. No. 44302/02, Eur. Ct. H.R. (2007), 43 Eur. H.R. Rep. 45 (2008) (Grand Chamber).

70. See, e.g., Madison Invs. v. Ham, [1984] 45 O.R. (2d) 563 (Can. Ont. C.A.). 
never in fact intended as a means of acquiring title, or as an encouragement to dishonest people to enter on the land of others with a view to deprive them of it."71 The basic concern is that the law not be used intentionally as an instrument of dispossession. This connects to a different aspect of the rule of law from its guidance function: its function of placing constraints on the exercise of power. Whatever else the law might be, it is not the mere instrument of domination. For the purposes of this paper it is not important which approach is correct-deference to statute or concern for the deliberate misuse of law-but that the debate is best understood as one that is framed by competing claims of the rule of law and different options for resolving those claims.

In all these ways we can see that one of the central doctrinal areas of the common law of property-possessory title-is marked by rule-of-law concerns regarding guidance. This influence can be properly discerned only once we understand two things: first, that the principle of publicity can be met through publicly understood practices that individuals can selfapply; and second, that the demands of guidance need to be understood in relation to both liability rules and legal powers. However, the rule of law is not exhausted by its guidance function, as the discussion of adverse possession also indicates. In the following section, I take up the second major aspect of the rule of law-its role in constraining the arbitrary exercise of power-and show how it, too, helps to shape the substantive law of property.

\section{NONARBITRARINESS AND TRESPASS}

If the guidance function of law is one of the ideas that organizes and underpins the principles of legality, the other is nonarbitrariness. That the rule of law provides constraints on the arbitrary exercise of power is, on some accounts, even more important than its guidance function. This is most striking in the criminal-law context, where one might think that the value of guidance is at its strongest because the consequences of not following the law are at their most severe. Yet when courts have examined criminal provisions under the void-for-vagueness doctrine in constitutional law, the central concern has been not notice to individuals but whether the law can properly constrain the enforcement discretion of legal officials. ${ }^{72}$

Many of Fuller's principles of legality can be interpreted in light of this concern regarding arbitrariness. General laws apply in the same way to all similarly situated individuals and do not single out individuals in an arbitrary manner. Laws that are public, clear, and prospective rather than secret,

71. Id. at para. 33, citing Harris v. Mudie (1883), 7 AR (Ont.) 414, at 421.

72. See, e.g., Kolender v Lawson, 461 U.S. 352 (1983); City of Chicago v. Morales, 527 U.S. 41 (1999). Canadian courts suggest that both notice to individuals and constraints on law enforcement discretion are at issue. See R. v Nova Scotia Pharm. Soc'y, [1992] 2 SCR 606; and Can. Found. for Children, Youth \& the Law v. Canada [2004] 1 S.C.R. 76. 
vague, and retrospective are less likely to give rise to arbitrary enforcement. But Fuller's eighth and final principle of legality is centrally concerned with arbitrariness-the requirement of congruity between official action and declared rule. He argues that this is "the most complex" of the principles of legality and can be undermined in various ways: "mistaken interpretation, inaccessibility of the law, lack of insight into what is required to maintain the integrity of a legal system, bribery, prejudice, indifference, stupidity, and the drive toward personal power."73

A focus on the common law's close integration between ideas of reason, community practices, and social order suggests several refinements regarding this principle of congruence that shift attention from the actions of officials to the self-application of law by the individuals whose lives are regulated by it. For example, as Simmonds argues, law that is difficult to comply with can lead to problems of congruence:

Suppose that the rules place various demands on citizens all of which are individually satisfiable, and the totality of which are jointly satisfiable in the sense that they do not directly conflict, let alone contradict one another; yet the rules do not add up to an intelligible and viable way of life which is compatible with the various projects that humans wish to pursue (enjoying some degree of material comfort, establishing close personal relations, pursuing work that may be of a potentially satisfying nature). Although technically possible to comply with, such rules would almost certainly encounter extensive non-compliance. Either vast resources would need to be expended upon relentless enforcement, or a substantial gap would develop between the law in the books, and the law as actually enforced. ${ }^{74}$

Although Simmonds puts this in fairly abstract terms of the congruence of legal doctrine with "an intelligible and viable way of life" we can see this concern reflected in the place that the common law routinely gives to considerations regarding the congruence of legal doctrine with actual social practice.

This principle of congruence, once articulated in relation to the individuals who must self-apply the law, can help to account for the strength of an owner's entitlement to exclude that we find in the law of property. Suppose that we had a system of ownership in which the boundaries of what is owned were completely clear but one's entitlement to exclusive control was subject to a range of potential limitations. These concerns might be factors that go to the underlying justification for property in some way, so that one had a right to exclude only in situations demanded by this justification. Or these might be factors that engage concerns broader than property, such as the social obligations of citizenship, which serve to limit one's right to 
exclude. ${ }^{75}$ Now consider the position of a nonowner who would like to use a particular thing or access a particular place. Despite knowing that it is owned and who owns it, the nonowner decides that the factors that defeat the owner's right to exclude are present and so proceeds to use the property without permission. Consider next the owner who, in weighing these same factors, comes to a different conclusion and insists that the nonowner is a trespasser. The problem is that if there are a variety of factors that need to be weighed in individual circumstances, then a gap potentially opens regarding the application of the law. This gap can be closed by referring disputes to the courts for resolution. However, in areas of the law that depend heavily upon the self-application of the law by individuals, this is not a workable option. Instead, once this gap opens, it will either be filled by informal social norms that do not reflect the law ${ }^{76}$ or simply provide a space for lawlessness.

We can see such concerns regarding a lack of certainty on the ground in the self-application of property norms throughout the common law of property. Consider the English Court of Appeal decision in London Borough of Southwark. There the court considered the defense of necessity in the context of a trespass claim against two homeless families who were squatting in houses owned by the local borough council. ${ }^{77}$ In deciding against the families, Lord Denning held that the defense of necessity must be "carefully circumscribed," for otherwise "necessity would open the door to many an excuse." As he argued:

If homelessness were once admitted as a defence to trespass, no one's house could be safe. Necessity would open a door which no man could shut. It would not only be those in extreme need who would enter. There would be others who would imagine that they were in need, or would invent a need, so as to gain entry. Each man would say his need was greater than the next man's. The plea would be an excuse for all sorts of wrongdoing. ${ }^{78}$

Justice Davies echoed these concerns in his concurring judgment, arguing that "the law regards with the deepest suspicion any remedies of self-help, and permits those remedies to be resorted to only in very special circumstances. The reason for such circumspection is clear-necessity can very easily become simply a mask for anarchy."79

75. See Gregory Alexander, The Social-Obligation Norm in American Property Law, 94 CORNELL L. REV. 745 (2009) (he seems to suggest that these are property norms, but this mixes up norms internal to the idea of property and norms that are about something else but nonetheless operate to limit property).

76. See Robert C. Ellickson, Of Coase and Cattle: Dispute Resolution among Neighbors in Shasta County, 38 Stan. L. REv. 624 (1986).

77. London Borough of Southwark v. Williams, [1971] All E.R. 175 (U.K.).

78. Id. at 179 .

79. Id. at 181 . 
The concerns here that motivate maintaining the very narrow scope of the defense of necessity are more about social order than they are about the idea of ownership. The worry is that broadening the scope of the defense to encompass ideas as broad and vague as "need" would open a large gap for arbitrariness in how individuals apply the law to their own circumstances. In other words, the narrowness of the defense of necessity in the context of trespass does not come from the judicial endorsement of a particular view of ownership per se but from judicial concerns regarding the rule of law.

This position is broadly consistent with the information-cost approach to property law. For example, Smith argues that there is a "gap" between property doctrines such as exclusive possession and a variety of justifications for ownership such that we can find numerous contexts in which exclusive possession is not justified. ${ }^{80}$ Nonetheless, he argues, departing from exclusive possession imposes too many information costs on third parties. On this view, the desirability of exclusive possession is tied not to a particular justification story for ownership but instead to the dynamic of information costs as they play out in a system of property. I agree with Smith that justificatory stories for ownership are of little relevance to understanding the right to exclude as it is expressed in legal doctrine. ${ }^{81}$ However, instead of information costs, I think that the important legal story is that of the rule of law. Clarity on the ground in terms of clear boundaries, clear title, and clear limits permits individuals to be guided by the law and reduces the scope for arbitrary self-application.

As a final example of rule-of-law concerns regarding arbitrariness operating in the other direction-pulling against the right to exclude rather than bolstering it-I want to look at the question of limits on an owner's right to exclude from property to which the public has been invited. To illustrate, consider the leading Canadian case regarding trespass in shopping malls, Harrison v. Carswell. ${ }^{82}$ This case is interesting because the issue was not framed in relation to the demands of freedom of expression or other ideas of constitutional values or human rights, as Canada at the time did not have its Charter of Rights and Freedoms. ${ }^{83}$ For the court, the central question was the legal significance of inviting the public onto one's property and whether this limited an owner's right to exclude.

One way to understand the potential significance of the public invitation was articulated quite clearly by Chief Justice Laskin in dissent. He suggested that historically the right to exclude protected one's privacy and that commercial property to which the public has been invited does not engage this justification. This is a fairly weak argument, as the right to exclude has been

80. Henry Smith, Mind the Gap: The Indirect Relation between Ends and Means in American Property Law, 94 CORNELl L. Rev. 959 (2009).

81. My point says nothing about its importance to broader questions of political morality.

82. Harrison v. Carswell, [1976] 2 S.C.R. 200 (Can.).

83. The Supreme Court of Canada has signaled that its decision would be the same even under the charter; see Comm. for Commonwealth of Can. v. Canada, [1991] 1 S.C.R. 139 at 228 (Can.) (McLachlin J.). See also Appleby v. United Kingdom, [2003] E.C.H.R. 222. 
defended on many grounds other than privacy. ${ }^{84}$ I want to suggest instead that the fact of inviting the public onto one's property generates the central legal question because this act engages rule-of-law concerns in a manner that other, more limited invitations do not.

Waldron argues that "it strains our ordinary concept of law to apply it to norms that address matters of personal or partial concern or institutions which make no pretense to operate in the name of the whole community, orienting themselves instead to the benefit of the individuals who control them." 85 In inviting the public to use your property, the rules that you set for your property take on a public quality that they otherwise do not have, because these rules, in effect, govern the public. The degree to which this is true will depend on the social context in which particular types of property are given public invitations. For example, it will likely be strongest when the property owner is in a monopoly-like situation with respect to socially important resources and not strong at all when members of the public can easily find substitutes with alternative terms of access. In other words, in some circumstances the act of inviting the public to use your property can transform rules regarding the use of your property from the expression of private inclinations to something that approximates lawmaking. This is why it pulls so strongly on judicial intuitions despite the many countervailing considerations; in general, the law will not tolerate private citizens purporting to govern the behavior of members of the public in an arbitrary manner. ${ }^{86}$

This is true even of the majority in Harrison v. Carswell. ${ }^{87}$ Despite declining to endorse an exception for picketing, Justice Dickson responded at length to the dissent's charge of supporting the "whimsy" of owners. He pointed out that the owner had a policy against all picketing, that there was academic support for the legitimate basis of such a policy, and that " $[t]$ here is nothing in the evidence supporting the view that in the present case the owner of the centre was acting out of caprice or whimsy or mala fides." ${ }^{" 88}$ In turn, Justice Dickson was motivated by other concerns regarding the role of the court in changing the law in an area that involved "difficult political and socio-economic issues, the resolution of which must, by their very nature,

84. There is also a strong argument to make that the historical association between privacy and property has more to do with ideas of the rule of law than with ideas of privacy. Many of the early search-and-seizure cases that were later interpreted to protect ideas of both property and privacy were centrally concerned with the scope of discretionary authority of the state. See generally Entick v. Carrington, (1765) 95 Eng. Rep. 807 (K.B.); Wilkes v. Wood, (1763) 98 Eng. Rep. 489 (K.B.); Thomas Y. Davies, Recovering the Original Fourth Amendment, 98 MicH. L. REv. 547 (1999); M. Blane Michael, Reading the Fourth Amendment: Guidance from the Mischief that Gave It Birth, 85 N.Y.U. L. REv. 905 (2010).

85. Waldron, The Concept and the Rule of Law, supra note 16.

86. For a very strong judicial expression of this view, see Uston v. Resorts Int'l Hotel, Inc., 89 N.J. 163, 445 A. 2d 370 (1982).

87. Harrison v. Carswell, [1976] 2 S.C.R. 200 (Can.).

88. Id. at 216. The academic support mentioned was in fact referred to in a very misleading manner as it actually endorsed the position of permitting labor picketing in malls. See H. W. Arthurs, Labour Law-Picketing in Shopping Centres, 43 CAN. BAR REv. 357 (1965). 
be arbitrary and embody personal economic and social beliefs." ${ }^{89}$ In other words, Justice Dickson responded to the charge of supporting the arbitrary decisions of owners by countering with a concern regarding the arbitrary decisions of judges. What is important for the purposes of this paper is that the dispute in the case can be framed as a dispute about the requirements of the rule of law and not a dispute about the nature of and justifications for ownership.

Although there are many reasons to view trespass rules as intrinsically tied to our core ideas of private ownership, this discussion shows that some important doctrinal elements arise out of rule-of-law values regarding arbitrariness rather than ideas of ownership per se. Just as in the previous discussions regarding the relationship between guidance and both control powers and title conditions, the rule of law operates in the practice of common-law reasoning by providing a set of legal principles that guide the practice of reasoning and help to create the legal framework within which ideas of community practices and social order are taken up. This deeply shapes the resulting substantive law.

\section{NONPROPERTY IMPLICATIONS}

This aim of this paper is to show the pervasive presence of the principles of legality in the practice of common-law reasoning and their resulting impact on the substance of common-law doctrine, in particular propertylaw doctrine. The introduction outlines the significance of this conclusion to a number of debates within property theory. In this final section I would like to outline some of the broader implications of this account in relation to our general understanding of common-law reasoning. While I mean only to sketch these implications here rather than offer a full defense in relation to contrasting accounts, I hope to show that calling into question the form/substance dichotomy regarding the rule of law has potentially farreaching implications for a number of other important debates regarding the nature of law and legal reasoning more generally.

The prevailing view of a divorce between form and substance has influenced accounts of legal reasoning-and therefore approaches to the common law-in a number of ways. For example, most discussions of the nature of legal reasoning either ignore rule-of-law considerations or construe their significance narrowly and formally in terms of support for the certainty of rules and precedent. ${ }^{90}$ Neil MacCormick stands out as an exception to this in his more sustained and nuanced attention to the rule of

89. Id. at 218 .

90. See generally EdWard H. Levi, An Introduction to Legal Reasoning (1949); Lloyd L.Weinreb, Legal Reason: The Use of Analogy in Legal Argument (2005); Melvin EisenBerg, The Nature of the Common Law (1991); William Twining \& David Miers, How to Do Things With Rules (5th ed. 2010); Frederick Schauer,Thinking Like a LaWyer (2009). 
law. ${ }^{91}$ MacCormick argues that the certainty usually associated with the rule of law needs to be reconciled with what he calls the "arguable character of law" - the idea that the content of the law is always open to contestationand he does so by pointing out that rule-of-law values go beyond certainty to encompass procedural requirements (such as the right to challenge a case against you in a fair and public process).

In contrast, I show how Fuller's principles of legality provide a much more complex understanding of the rule of law than simply the idea of certainty. Moreover, once we uncover the role of the principles of legality in the practice of common-law reasoning, we can see that the rule of law is not in tension with legal argument but is part of what constitutes it as a distinctively legal form of reasoning. The character of law might be "arguable," but its arguability follows distinctive contours that are shaped by the rule of law. For example, as I argue in numerous examples throughout this paper, many of the ways in which common-law reasoning takes up considerations of community practices and ideas of social order are governed by rule-of-law considerations.

Since Dworkin's influential work on the interpretive nature of law, many theorists have thought about the "principles" routinely invoked in commonlaw reasoning in terms of principles of substantive justice and political morality. ${ }^{92}$ In contrast, my position suggests that many of these principles are best understood more narrowly as expressions of the formal aspects of the rule of law. Take, for example, Dworkin's well-known example of Riggs v. Palmer and its reliance on the principle that wrongdoers should not profit from their wrong. ${ }^{93}$ The Supreme Court of Canada has held that the significance of this principle lies in preventing an inconsistency in the law that would arise if courts were "in the position of saying that the same conduct is both legal, in the sense of being capable of rectification by the court, and illegal." 94 Consistency, understood in this case in terms of noncontradiction, is one of the principles of legality and here explains the scope of the wrongdoing principle without reference to ideas of substantive justice or political morality.

Part of the difficulty for Dworkin stems from his views regarding legality. While he agrees that a conception of legality - what he calls the aspirational account of law-helps to frame doctrinal interpretation, his own account of legality is exhausted by the concepts of procedural fairness and substantive justice. ${ }^{95}$ The principles of legality that Fuller articulates and that I argue are central to common-law reasoning are for Dworkin part of a "sociological" concept of law-for him a relatively imprecise idea aimed at determining

91. MACCORMICK, supra note 36; see also Weinrib, supra note 3.

92. RONALD DWORKIN, LAW's EMPIRE (1988).

93. Id. at 15-20, citing Riggs v. Palmer, 22 N.E. 188 (N.Y. 1889).

94. Hall v. Hebert, [1993] 2 S.C.R. 159 (Can.); See also Ernest J. Weinrib, Illegality as a Tort Defence, 26 U. TORONTO L.J. 28 (1976).

95. Ronald DWorkin, Justice in Robes (2006). 
whether some social institution is best labeled law, but irrelevant to doctrinal questions. ${ }^{96}$ Because of this, Dworkin does not see their importance to the practice of legal reasoning. While it is true that legal reasoning is concerned with providing a justification for a particular decision, the principles of justification that courts draw upon are not necessarily deep principles of substantive justice but principles that ensure that their decisions are consistent with the formal aspects of the rule of law.

It may be that some common-law decisions look like Herculean exercises of interpretation of our deepest commitments of substantive justice rather than judgments regarding the demands of legality. However, creating a theory of legal interpretation that ignores the role that the principles of legality play in doctrinal disputes distorts Dworkin's account of legal reasoning. This distortion is serious for any interpretive account of law, for if one takes the principles invoked by judges to be principles that engage questions of substantive justice, then the interpretive exercise that renders these in their best light will be quite different from if one recognizes that many of these principles engage questions of legality rather than justice. ${ }^{97}$

If Dworkin champions the role of the principles of substantive justice in legal reasoning, it is Posner who champions the role of policy considerations. ${ }^{98}$ Part of Posner's argument for the form of pragmatic reasoning that he advocates is that "legalism" cannot provide judges with the basis for decisions in difficult cases and that these difficult cases require judges to engage in broad policy determinations. However, this argument takes as its foil a very simplistic view of legalism. For example, he describes the position of "legalism" in the following terms:

Legalism ... hypothesizes that judicial decisions are determined by "the law," conceived of as a body of preexisting rules found stated in canonical legal materials, such as constitutional and statutory tests and previous decisions of the same or a higher court, or derivable from those materials by logical operations. ${ }^{99}$

96. This is a very strange label, given the fact that Fuller himself used the language of legality and called it a matter of aspirational morality.

97. This might be overstating the separation between the formal principles of legality and substantive principles of justice. One feature of Fuller's account that I find striking is the role that the concept of human dignity plays in animating his principles. This leaves open the question of whether a substantive legal norm that flagrantly violated any idea of human dignity could in fact be a legal norm. However, the particular content demanded by the idea of dignity is something that is deeply contested. And this connects to the substantive principles that Fuller himself suggested might be demanded by his account: "Open up, maintain, and preserve the integrity of the channels of communication by which men convey to one another what they perceive, feel, and desire." See Fuller, supra note 1, at 186.

98. Richard A. Posner, How Judges Think (2008).

99. $I d$. at 41 . He points out ( $i d$. at 48 ) that even originalists who have narrow views regarding the interpretation of statutes and constitutional provisions are more moderate in relation to the common law, recognizing a stronger role for judicial discretion. 
In contrast, Posner argues that we must face the fact that judges exercise considerable discretion, that legalism cannot constrain this discretion in the manner claimed, and that we should frankly face the fact that judges engage in policy.

However, the view of "legality" presented in this paper is quite different from Posner's caricature of "legalism." If we understand the common law in terms of a social practice of reasoning deeply shaped by rule-of-law values, then we can see that the material that judges can draw upon in rendering their decisions is not as limited as Posner suggests. common-law judges do indeed make consequentialist arguments, often in relation to the general considerations of community practices and social order that I discuss in various examples. The important point that I am stressing is that these considerations are taken up in service of rule-of-law values. The principles of legality are important considerations that constrain judicial discretion and seek to ensure that any resulting decision is indeed a decision consistent with the practice of law rather than something else. However, even Fuller is clear that the principles of legality may conflict in particular cases and are an "aspiration" that may be achieved to a greater or lesser extent. Therefore Fuller can agree with the position that there is no right answer in difficult cases and that these cases require exercises of judgment rather than logical deduction.

But the further position that therefore judges are engaged in extralegal reasoning simply does not follow. On my account, there is no reason to endorse a view of judging that posits as a normative matter that when judges are called upon to exercise discretion they should draw upon their personal experiences, psychology, and ideology unconstrained by legal considerations. That they may in fact do this is human nature. Reducing the scope of this is what it means to be a society governed by the rule of law.

\section{CONCLUSION}

I suggest in this article that we can begin to see the pervasiveness of the influence of rule-of-law values on the common law of property once we move away from an understanding of the core principles of legality as indicating formal properties that "norms" or "rules" must conform to and instead see the constitutive role that these considerations play in the social practice of common-law reasoning. In this way, although these principles are formal they can influence and even generate substantive doctrine in a complex manner.

Reframing of the form/substance debate in relation to the rule of law and property law in the manner I outline has implications for property law and implications that go beyond property law. The implications for property law include the conclusion that the rule of law is an intrinsic part of the common law of private ownership. However, by showing that the substantive 
norms of "ownership" cannot be neatly separated from the rule-of-law values that are important in their interpretation and development, this conclusion opens the possibility that part of what we find valuable in relation to the norms of ownership is the rule of law rather than ownership per se. This, in turn, raises the possibility that other forms of legal ordering in relation to places or things can also be consistent with rule-of-law values. Therefore, unlike the rule-of-law formalists, my account accepts that private ownership is indeed intrinsically bound up with the rule of law; unlike the rule-of-law substantivists, my account suggests that private ownership is not necessarily required by the rule of law.

But because at the heart of this reframing of the form/substance dichotomy lies an account of the relationship between common-law reasoning and the principles of legality, its implications extend beyond property and out to theories of law more generally. In particular, this reframing points to the need to take seriously the significance of the rule of law in the context of legal reasoning and the practice of legal justification. As I suggest here, we might agree with Dworkin that there are important principles in the common law and we might also agree with Posner that there is a role for consequentialist claims in the common law, but the best way to understand both is through the framework of the rule of law. 